\title{
Susceptibility of two strains of rainbow trout Oncorhynchus mykiss to experimentally induced infections with the myxosporean Ceratomyxa shasta
}

\author{
A. M. Ibarra ${ }^{1}$, G. A. E. Gall ${ }^{1}$, R. P. Hedrick ${ }^{2, *}$ \\ 'Aquaculture and Fisheries Program, Department of Animal Science, University of California, Davis, California 95616, USA \\ ${ }^{2}$ Aquaculture and Fisheries Program, Department of Medicine, School of Veterinary Medicine, University of California, Davis, \\ California 95616, USA
}

\begin{abstract}
Two strains of rainbow trout Oncorhynchus mykiss were examined for their susceptibility to ceratomyxosis by intraperitoneal injection with developmental and sporogonic stages of Ceratomyxa shasta obtained from fish with naturally acquired infections. Both the C. shasta-susceptible (Mt. Shasta) and $C$. shasta-resistant (Pit River) strains succumbed to infections induced by the greatest concentration of parasites administered, with mean times to death of 17 and $16 \mathrm{~d}$, respectively. In groups receiving an intermediate dose of parasites, $100 \%$ of Mt. Shasta fish and $82 \%$ of Pit River fish died. Mean time to death for both strains was $27 \mathrm{~d}$. At the lowest dose examined only $13 \%$ of the Pit River strain died over the study period of $53 \mathrm{~d}$ compared to $90 \%$ of the Mt. Shasta strain. The mean times to death for the Pit River and Mt. Shasta strains were 29 and $36 \mathrm{~d}$, respectively. The lower mortality observed among the Pit River fish suggests that a component of the resistance seen in certain strains of trout is due to defense factors at a stage beyond prevention of penetration or invasion of the infective stage of C. shasta.
\end{abstract}

\section{INTRODUCTION}

Ceratomyxa shasta is a histozoic myxosporean parasite of salmonid fish of the west coast of the USA and Canada. As opposed to all other species in the genus, C. shasta infects fish in freshwater rather than the marine environment (Noble 1950). Ceratomyxosis was first detected in rainbow trout Oncorhynchus mykiss in northern California at the Crystal Lake Hatchery and the causative agent was described by Noble (1950). The geographic range of the parasite is limited to salmonids in California, Oregon, Idaho, Washington, and British Columbia (Bartholomew et al. 1989a, Hendrickson et al. 1989).

Although most salmonids are susceptible to this parasite, a range of responses between different species, as well as strains within species, has been demonstrated (Zinn et al. 1977, Buchanan et al. 1983, Hemmingsen et al. 1986). Since resistant strains of salmonids originate from areas where the parasite is

- Addressee for correspondence believed to have been enzootic, natural selection has been suggested as the cause for development of resistance. The mechanisms(s) which provides for resistance among these strains of salmonids, however, remains unknown. Two principal mechanisms for the resistance have been proposed; (1) penetration or invasion of the infective stage of Ceratomyxa shasta is prevented by a barrier at the site of entry (Bartholomew et al. 1989b) and, (2) the existence of qualitative or quantitative differences in the immune response of resistant compared to susceptible trout strains (Ratliff 1981)

Although ceratomyxosis has been experimentally induced by intraperitoneal injection of ascitic fluid from infected fish into susceptible fish (Johnson et al. 1979, Bower 1985), the consequences of experimental injection of the parasite into fish from strains known to be resistant to Ceratomyxa shasta (under natural exposures) have not been reported. In the present study, we examined the response of 2 strains of rainbow trout Oncorhynchus mykiss, a resistant and a susceptible, to experimentally induced infections with $C$. shasta. Differences in the response of the 2 strains were deter- 
Table 1. Oncorhynchus mykiss. Mortality and time to death ( \pm SE) among the susceptible strain, Mt. Shasta, and the resistant strain, Pit River, of rainbow trout following intraperitoneal injections with Ceratomyxa shasta

\begin{tabular}{|c|c|c|c|c|}
\hline & \multicolumn{4}{|c|}{ Dilution $^{\text {a }}$} \\
\hline \multicolumn{5}{|l|}{ Mt. Shasta strain } \\
\hline No. injected & 50 & 47 & 48 & 50 \\
\hline \multicolumn{5}{|l|}{ Mortality } \\
\hline Number & 50 & 47 & 43 & 0 \\
\hline (Percent) & $(100)$ & $(100)$ & $(90)$ & - \\
\hline Mean time to death & $17( \pm 0.72)$ & $27( \pm 1.06)$ & $36( \pm 1.16)$ & - \\
\hline Survivors & 0 & 0 & $5^{c}$ & 50 \\
\hline \multicolumn{5}{|l|}{ Pit River strain } \\
\hline No. injected & 48 & 50 & 48 & 49 \\
\hline \multicolumn{5}{|l|}{ Mortality } \\
\hline Number ${ }^{b}$ & 48 & 41 & 6 & 0 \\
\hline (Percent) & $(100)$ & $(82)$ & (13) & - \\
\hline Mean time to death & $16( \pm 0.45)$ & $27( \pm 1.22)$ & $29( \pm 4.74)$ & - \\
\hline Survivors & 0 & 9 & $42^{d}$ & 49 \\
\hline \multicolumn{5}{|c|}{$\begin{array}{l}\text { a Fish were injected with undiluted }\left(10^{\circ}\right) \text { and } 2 \text { serial } 10 \text {-fold dilutions of freshly collected ascites from trout with natural } \\
\text { infections with } C \text {. shasta. Controls received only minimal essential medium } \\
\text { b All dead trout were examined for presence of the parasite by scraping the lower intestine and observing at } 400 \times \text {. All fish } \\
\text { dying during the experiment were found infected with C. shasta. } \\
\text { c Three of the } 5 \text { survivors were positive for spores in the posterior intestine at the end of the experiment (Day 53) } \\
\text { d One of the } 42 \text { survivors was positive for spores in the posterior intestine at the end of the experiment (Day 53) }\end{array}$} \\
\hline
\end{tabular}

mined from mortality after $53 \mathrm{~d}$ and time to death following initial injection of known concentrations of developmental and sporogonic stages of C. shasta.

\section{MATERIALS AND METHODS}

Fish. Two hundred uninfected rainbow trout from each of 2 strains, a highly Ceratomyxa shasta susceptible strain (Mt. Shasta) and a C. shasta-resistant strain (Pit River), were transported from the State of California Crystal Lake Hatchery to the Fish Disease Laboratory at the University of California, Davis. Fish of each strain of trout were divided into 4 groups of ca 50 fish and placed into $130 \mathrm{l}$ tanks receiving $15^{\circ} \mathrm{C}$ well water. Average weights of the Mt. Shasta and Pit River trout were 16 and 7 g, respectively, and the fish of both strains were ca 6 mo of age. The use of different sizes for the 2 rainbow trout strains of the same age was unavoidable because of the different growth rates of these 2 strains. To control potential secondary bacterial infections originating from the ascitic fluids used to initiate experimental infections, all fish were fed a medicated (oxytetracycline $3.86 \mathrm{~g}$ $\mathrm{kg}^{-1}$ feed) dry trout diet once daily at ca $3 \%$ of body weight.

\section{Experimental infections.}

Preparation of inocula: Experimental infections were induced in duplicate groups of trout, one for each strain, by injection of ascitic fluid containing parasites col- lected from rainbow trout with naturally acquired ceratomyxosis. Briefly, ascites was aspirated with sterile syringes and needles from the peritoneal cavity of 7 infected trout (Mt. Shasta strain). The 7 samples of aspirated ascites were pooled (total volume $15 \mathrm{ml}$ ) and stirred on a vortex mixer prior to use.

Injection of fish: Three experimental groups, each with 47 to 50 trout of each strain, received $0.1 \mathrm{ml}$ per fish of either undiluted ascites or one of 2 serial 10 fold dilutions in minimal essential medium (MEM), i.e. $10^{-1}$ or $10^{-2}$. The number and developmental stages of the parasites in each inocula were determined by hemocytometer counts. The inocula $(0.1 \mathrm{ml})$ for the groups injected with undiluted ascites contained an estimated 216000 total parasites, of which 55000 were sporogonic stages and the remainder trophozoites. The fish injected with the first dilution of ascites $\left(10^{-1}\right)$ were inoculated $(0.1 \mathrm{ml})$ with an estimated 19600 total parasites, of which 5000 were sporogonic stages. For the second dilution $\left(10^{-2}\right), 0.1$ $\mathrm{ml}$ of the inocula contained an estimated 1790 total parasites of which 455 were sporogonic stages. A control group of each strain of trout received an injection of $0.1 \mathrm{ml}$ of MEM per fish

Parasite detection: Mortalities were collected daily and examined for presence of developmental or sporogonic stages of Ceratomyxa shasta by microscopic examinations of posterior intestinal scrapings at $400 \times$. When present, ascites was also examined. The experiment was terminated $53 \mathrm{~d}$ after initial injection and all 
surviving fish were examined for presence of parasites in the posterior intestine.

Statistical analysis. Differences in mortality between the 2 rainbow trout strains were compared using a $Z$ test for Normal Approximation to the Binomial. Differences in mean time to death between doses were compared by confidence intervals using a t-test. Statistical significance for both analyses was $\mathrm{p} \leq 0.05$.

\section{RESULTS}

\section{Mortality and mean time to death}

Both strains of trout suffered $100 \%$ mortality when ceratomyxosis was experimentally induced with undiluted ascites (Table 1). The mean time to death at this dose was $16 \mathrm{~d}$ post-injection for the smaller Pit River strain and $17 \mathrm{~d}$ for the Mt. Shasta strain. Injection of a $10^{-1}$ dilution resulted in $100 \%$ mortality of the $\mathrm{Mt}$. Shasta strain and $82 \%$ of the Pit River strain by $53 \mathrm{~d}$ post-injection. Mean time to death for both the susceptible and resistant strains was $27 \mathrm{~d}$. A greater difference in mortality between strains was observed at the $10^{-2}$ dilution, where $90 \%$ of the Mt. Shasta strain died compared to only $13 \%$ of the Pit River strain. The mean times to death for the Mt. Shasta and Pit River strains were 36 and $29 \mathrm{~d}$, respectively. All mortalities were presumed to be due to Ceratomyxa shasta as determined by the presence of numerous parasites in intestinal scrapings. There were no mortalities in either of the control groups.

Among the fish surviving experimental infection, 3 of the $5 \mathrm{Mt}$. Shasta survivors and 1 of the 42 Pit River survivors at $10^{-2}$ were positive for developmental or sporogonic stages when examined at the end of the experiment. None of the 9 Pit River survivors at $10^{-1}$ had parasites at the end of the experiment (Table 1).

\section{DISCUSSION}

The presence of resistance among strains of trout and salmon has been shown to exist in geographical regions where Ceratomyxa shasta is enzootic (Zinn et al. 1977, Johnson et al. 1979, Ratliff 1981, Buchanan et al. 1983, Ching 1984, Ching \& Munday 1984, Hemmingsen et al. 1986). Bartholomew et al. (1989b) found trophozoites among $2 / 150$ resistant rainbow trout (North Santiam strain) $30 \mathrm{~d}$ following natural exposure to $C$. shasta at a water temperature of $12^{\circ} \mathrm{C}$. In one fish, a single parasite was detected in the lumen of the intestine while the second fish had a severe infection of the intestine similar to that seen in parallel groups of susceptible trout (Siletz River strain). These observa- tions led to the suggestion that resistance is associated with prevention of the initial invasion or penetration, which if breached, may result in infections not unlike those found in susceptible trout.

Direct injection of the parasite evades the normal barriers that might prevent invasion and/or initial reproduction. In our study we observed a similar progression of the disease after introducing trophozoites and sporogonic stages of Ceratomyxa shasta by injection in both resistant and susceptible strains of trout when a high dose of parasite was injected, as evidenced by the lack of significant differences between strains for mortality and mean time to death. However, a significant difference in mortality $(p<0.05)$ was observed between resistant and susceptible fish receiving 2 lower doses of parasites via intraperitoneal injection. These results suggest that there are inherent factors associated which can prevent the spread of infection in resistant strains. Whether these are a result of direct effects of the immune response however, is unknown.

The Pit River strain is quite resistant to natural exposures to Ceratomyxa shasta, as shown by mortalities of $3 \%$ following $157 \mathrm{~d}$ exposure compared with 99 to $100 \%$ for Mt. Shasta strain fish at the same age and under the same exposure conditions (unpubl.). However, this resistance to C. shasta infections among Pit River trout can be overwhelmed as demonstrated by injection of a high dose as in the present study.

Although a dose effect was not evident for the mortalities among the Mt. Shasta strain, there were significant differences $(p<0.05)$ in mean time to death between doses. The highest dose $\left(10^{\circ}\right)$ resulted in the fastest time to death followed by the intermediate and lowest dose, in which time to death was twice that observed in the highest dose. Among the Pit River fish, a dose effect was evident also for mean time to death between the 2 highest doses $(p<0.05)$. Despite the size differences between the 2 strains at injection, there were no strain differences $(p>0.05)$ in mean time to death for the 2 higher doses. Only 6 Pit River fish succumbed to the experimental injection in the lowest dose $\left(10^{2}\right)$ and their mean time to death was not significantly different from any of the other treatment.

In conclusion, although our results do not identify any specific mechanisms by which resistant trout prevent Ceratomyxa shasta infections, they do indicate that components besides the possible prevention of invasion and initial multiplication by the infective stage may contribute to resistance in certain strains of trout. These may include nonspecific or an enhanced cellular immune response. Preliminary histological examinations of survivors of experimentally-induced infections with C. shasta among Mt. Shasta and Pit River strains suggest that a more effective containment of the 
parasite occurs in resistant fish. Some of the Pit River strain fish had well-defined granulomas surrounding degenerative stages of the parasite (unpubl.). Further studies examining this apparent difference in host response are underway.

Acknowledgements. This work was supported in part by Dingell/Johnson - Wallop Breaux Fish Restoration Act Funds under Project No. F-50-R, U.S. Fish and Wildlife Service. We greatly appreciate the statistical assistance of Dr T R. Famula.

\section{LITERATURE CITED}

Bartholomew, J. L., Rohovec, J. S., Fryer, J. L. (1989a). Ceratomyxa shasta, a myxosporean parasite of salmonids. Fish Dis. Leaflet 80, U.S. Fish and Wildlife Service

Bartholomew, J. L., Smith, C. E., Rohovec, J. S., Fryer, J. L. (1989b). Characterization of a host response to the myxosporean parasite, Ceratomyxa shasta (Noble), by histology, scanning electron microscopy and immunological techniques. J. Fish Dis. 12: 509-522

Bower, S. M. (1985). Ceratomyxa shasta (Myxozoa: Myxosporea) in juvenile chinook salmon (Oncorhynchus tshawytscha): experimental transmission and natural infections in the Fraser River, British Columbia. Can. J. Zool. 63: 1737-1740

Buchanan, D. V., Sanders, J. E., Zinn, J. L., Fryer, J. L. (1983). Relative susceptibility of four strains of summer steelhead

Responsible Subject Editor: W. Körting, Hannover, Germany to infection by Ceratomyxa shasta. Trans. Am. Fish. Soc. 112: $541-543$

Ching, H. L. (1984). Comparative resistance of Oregon (Big Creek) and British Columbia (Capilano) juvemile chinook salmon to the myxozoan pathogen, Ceratomyxa shasta, after laboratory exposure to Fraser River water. Can. J. Zool. 62: 1423-1424

Ching, H. L., Munday, D. R. (1984). Susceptibility of six Fraser chinook salmon stocks to Ceratomyxa shasta and the effects of salinity on ceratomyxosis. Can. J. Zool. 62 $1081-1083$

Hemmingsen, A. R., Holt, R. A., Ewing, R. D., McIntyre, J. D. (1986). Susceptibility of progeny from crosses among three stocks of coho salmon to infection by Ceratomyxa shasta. Trans. Am. Fish. Soc. 115: 492-495

Hendrickson, G. L., Carleton, A., Manzer, D. (1989). Geographic and seasonal distribution of the infective stage of Ceratomyxa shasta (Myxozoa) in Northern California. Dis. àquàt. Org. $7 \cdot 165-169$

Johnson, K. A., Sanders, J, E., Fryer, J. L. (1979). Ceratomyxa shasta in salmonids. Fish Dis. Leaflet 58, U.S. Fish and Wildlife Service

Noble, E. R. (1950). On a myxosporidian (protozoan) parasite of California trout. J. Parasitol. 36:457-460

Ratuiff, D. E. (1981). Ceratomyxa shasta: epizootiology in chinook salmon of central Oregon. Trans. Am. Fish. Soc. 110: $507-513$

Zinn, J. L., Johnson, K. A., Sanders, J. E., Fryer, J. L. (1977) Susceptibility of salmonid species and hatchery strains of chinook salmon (Oncorhynchus tshawytscha) to infections by Ceratomyxa shasta. J. Fish. Res. Bd Can. 34: 933-936

Manuscript first received: October 29, 1990

Revised version accepted: February 12, 1991 